\title{
PERSEPSI TERHADAP PICTORIAL HEALTH WARNING IKLAN LUAR RUANG PRODUK ROKOK
}

\author{
Centurion Chandratama Priyatna dan Anwar Sani \\ Program Studi Humas, Fakultas Ilmu Komunikasi, Universitas Padjadjaran
}

\begin{abstract}
This research emphasizes on Pictorial Health Warning (PHW) in outdoor media of cigarettes product's advertisement, focusing on smoker's perception towards pictorial health warning of "A man smoking with the skull shaped smokes" variant.

This study uses qualitative descriptive method exploring the perception on the particular pictorial health warning variant. Informants in this research are located in several big cities in Indonesia. The purpose of this research is to enrich the body of knowledge on health communication, especially on the danger of smoking, and also enforcing government in the effort of communicating the hazardous of smoking towards its public.
\end{abstract}

Key words: pictorial health warning, cigarette, outdoor advertisement

\section{PENDAHULUAN}

Pemerintah Indonesia dalam rangka meningkatkan kesehatan masyarakat telah berupaya untuk mengurangi jumlah perokok dengan berbagai peraturan dan aturan yang membatasi industri rokok dalam penjualan produknya. Pembatasan itu mulai dengan menaikkan cukai, pembatasan promosi rokok, serta pencantuman peringatan kesehatan pada kemasan dan iklan produk rokok. Salah satu cara yang dilakukan adalah dengan mengeluarkan Peraturan Pemerintah 109/2012 yang mengatur mengenai tata cara pengamanan bahan yang mengandung zat adiktif, yaitu produk tembakau. Implementasi peraturan ini dilaksanakan dengan disahkannya peraturan Menteri Kesehatan nomor 28 tahun 2013, yang mengatur mengenai pencantuman peringatan kesehatan dan informasi kesehatan pada kemasan produk tembakau. Pencantuman peringatan kesehatan dan informasi kesehatan ini juga berlaku untuk semua materi promosi dan iklan dari produk rokok.

Pasal 14-17 PP 109/2012 mengatur pencantuman gambar dan tulisan berisi peringatan atas bahaya merokok baik dalam kemasan maupun dalam materi promosi produk rokok. Iklan dan promosi tembakau harus mencantumkan gambar dan tulisan peringatan merokok sebesar $10 \%$ dari 
durasi iklan atau 15\% dari total luas iklan (PP 109/2012 pasal 27). Gambar peringatan merokok (Pictorial Health warning) yang harus dicantumkan pada kemasan produk rokok dan juga iklan rokok tersebut terdiri dari lima varian dengan tiga varian menunjukkan penyakit yang ditimbulkan oleh rokok dan dua varian menunjukkan kebiasaan buruk dalam merokok, seperti terlihat dalam gambar di bawah ini:

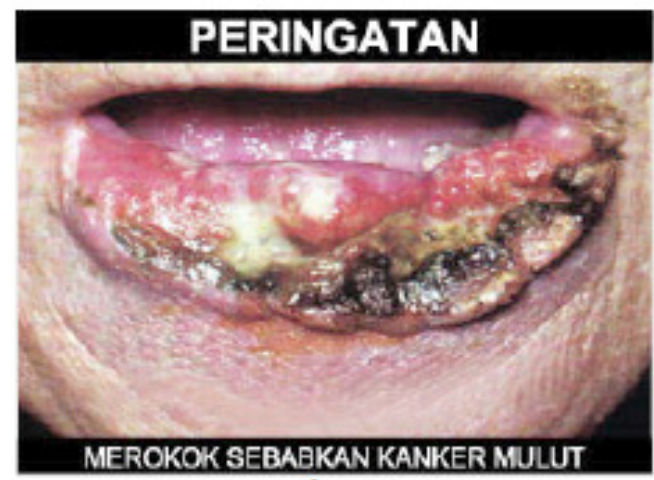
gambar 1

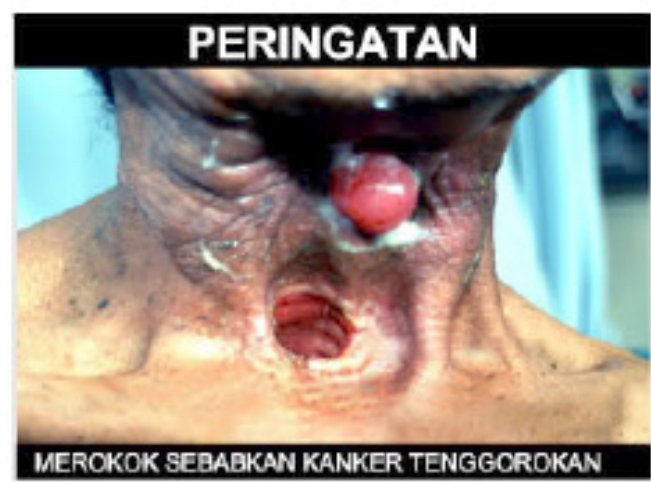

gambar 3

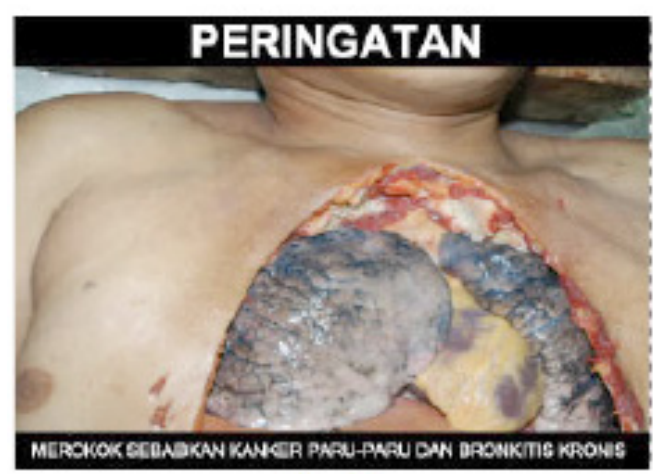

gambar 5

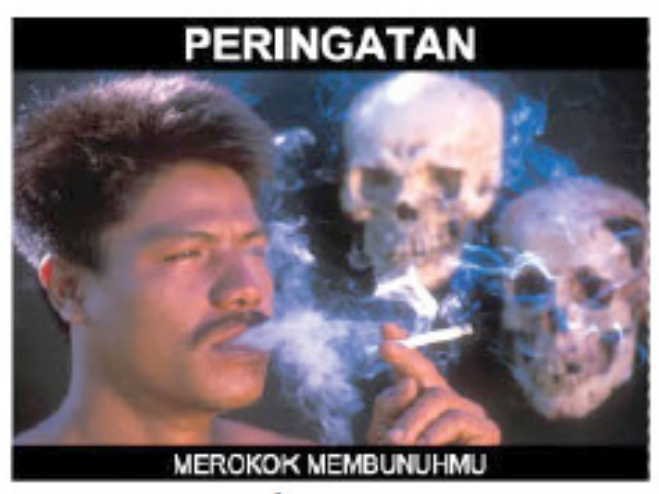

gambar 2

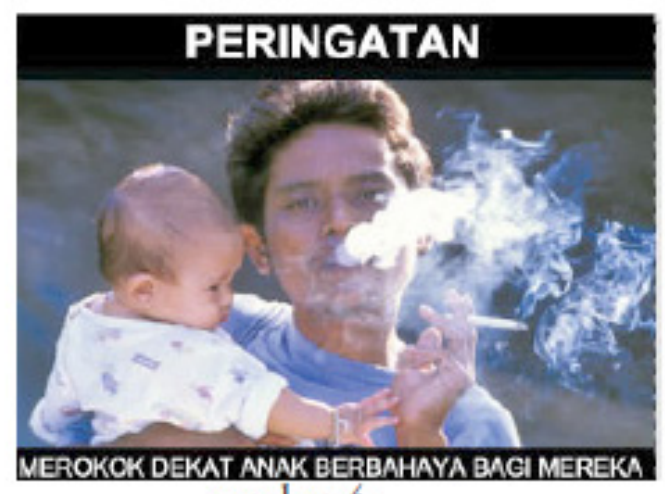

gambar 4

Gambar 1. Lima Varian Pictorial Health Warning Sumber: Lampiran Peraturan Menteri Kesehatan RI no.28/2013 
Dari kelima PHW tersebut diatas, fokus dari penelitian ini akan tertuju pada varian nomor 2 yaitu gambar orang merokok dengan asap yang membentuk tengkorak. Hasil observasi lapangan menunjukkan bahwa hampir 90\% dari iklan media luar ruang iklan rokok menggunakan PHW ini (Priyatna \& Sani, 2014). Adapun penyebabnya menurut Andi Sari Bunga Untung dalam Priyatna dan Sani (2014) karena aturan mendetail mengenai implementasi PHW dalam iklan belum dikeluarkan oleh pemerintah, dimanfaatkan oleh produsen rokok yang lebih memilih PHW yang paling tidak mengganggu (menjijikan) bagi para audience. Karena banyaknya penggunaan PHW varian seperti terlihat di bawah ini dalam iklan media luar ruang produk rokok maka penelitian ini bermaksud membedah persepsi yang ada di masyarakat mengenai hal ini dengan menggunakan studi deskriptif kualitatif.

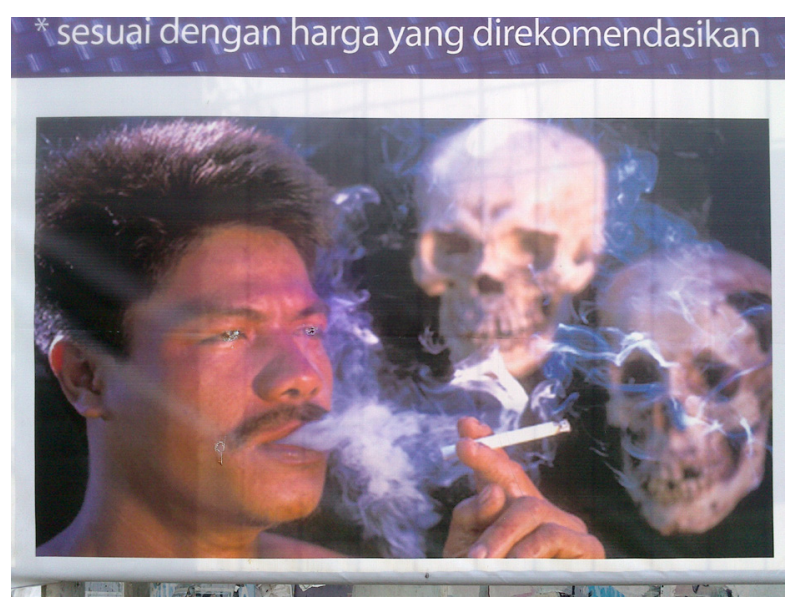

Gambar 2. Varian PHW Gambar orang merokok dengan asap yang membentuk tengkorak Sumber: Koleksi Pribadi
Bagian ini akan membahas mengenai elemen-elemen penting yang ada dalam penelitian ini seperti Pictorial Health Warning (PHW), budaya merokok, dan media luar ruang.

Pictorial Health Warning/Gambar Peringatan Kesehatan Implementasi dari Pictorial health warning (PHW) adalah buah dari Framework Convention of Tobacco Control (FCTC) yang dideklarasikan oleh World Health Organization (WHO) di tahun 2005 (World Health Organization, 2005). Di Indonesia, dalam hal ini pemerintah Republik Indonesia, mencoba mengimplementasikan FCTC melalui PHW walaupun Republik Indonesia belum ikut meratifikasi FCTC tersebut. Efektifitas PHW menurut penelahaan Deutsches Krebsforschungszentrum (DFZ) dapat mencegah anak muda/remaja untuk merokok, memotivasi perokok untuk berhenti, dan mencegah mantan perokok untuk kembali merokok (Deutsches Krebsforschungszentrum , 2013).

PHW sesuai PP 109/2012 dan Permenkes 28/2013 memiliki banyak kesamaan dengan PHW menurut FCTC, salah satun persamaanya adalah keberadaan aturan mengenai prosentase yang harus ditutup oleh PHW pada kemasan rokok (PP 109/2012 dan FCTC). PHW di bungkus produk tembakau dalam PP 109/2012 mensyaratkan luas minimal sebesar 40\% sedangkan FCTC mensyaratkan luas 50\% atau lebih dengan minimal luas 30\% pada area utama kemasan rokok (World Health Organization, 2005). 
Tidak adanya PHW dalam iklan atau promosi produk tembakau di dalam FCTC karena WHO menganggap bahwa pelarangan produk tembakau untuk berpromosi secara komprehensif akan mengurangi konsumsi produk tembakau (World Health Organization, 2005). Sedangkan di Indonesia sendiri PHW dalam iklan atau promosi produk tembakau di Indonesia memiliki regulasi yang diatur dalam PP 109/2012, dengan mengambil $10 \%$ dari total durasi iklan dan/atau $15 \%$ dari total luas iklan.

PHW menurut WHO dapat meningkatkan kesadaran public akan bahaya penggunaan produk tembakau dan sangat efektif dari segi pembiayaan (WHO, 2014). Pemerintah Republik Indonesia telah melaksanakan aturan pemasangan PHW dalam kemasan rokok terhitung 24 Juni 2014 dan di tanggal 27 Juni 2014 perusahaan rokok yang mendaftarkan diri untuk mencantumkan PHW meningkat dari 41 menjadi 56 dari total 672 perusahaan (Sekjen Kementrian Kesehatan RI, 2014), merek rokok yang sudah terdaftar untuk mencantumkan PHW juga meningkat dari 208 menjadi 326 merek dari total 3.363 perusahaan (Sekjen Kementrian Kesehatan RI, 2014). Namun begitu, PHW dalam media promosi produk rokok belum diatur oleh pemerintah untuk menggunakan keseluruhan varian yang ada sehingga masih banyak media promosi produk rokok yang hanya menggunakan varian yang dianggap paling tidak mengganggu audience untuk tiap iklan baik yang berbentuk elektronik, cetak, maupun luar ruang.
Budaya merokok di Indonesia sendiri dibawa oleh orang orang eropa di awal abad ke-17 (Hanusz, 2000, p. 10). Walaupun telah dibawa sejak lama, merokok tidak serta merta menjadi budaya Indonesia karena pada saat itu memakan sirih masih menjadi budaya utama. Merokok menjadi pengganti budaya memakan sirih ketika kebijakan pemerintah kolonial Belanda ingin memodernisasikan dan mendidik rakyat Indonesia (Arnez, 2009, p. 50). Di akhir abad 19 dan awal abad 20, orang Indonesia yang menerima pendidikan semakin banyak karena adanya politik etis yang terbukti meningkatkan ekonomi akibat dari peningkatan pendidikan (Ricklefs, 1993, pp. 151-152). Semakin tinggi tingkat pendidikan yang diterima oleh orang Indonesia pribumi inilah yang mengakibatkan perubahan kebiasaan makan sirih menjadi merokok, karena merokok dianggap sebagai simbol barat dan juga karena makan sirih diangggap kuno, menjijikan, dan juga menunjukkan inferioritas (Arnez, 2009, p. 51) (Arnez, 2009, p. 50). Dari refleksi tersebut Reid menyimpulkan bahwa terdapat implikasi yang signifikan dari perubahan kebiasaan makan sirih menjadi merokok:

The shift from betel to tobacco has important social implications. Whereas betel-chewing pre-eminently symbolized the union of male and female, cigarette-smoking has become one of the most important symbols of the expanding modern sector of economy which is dominated by men, in contrast to an older agricultural market economy in which women were prominent. (Reid, 1985) 
Merokok juga merupakan ritual yang diwariskan para pendahulu dalam bentuk ritual Hindu yang dicampurkan dengan ajaran Islam, sesajen yang dibuat selalu ditambahkan rokok kretek di dalamnya (Hanusz, 2000, p. 161). Merokok juga dianggap sebagai salah satu tindakan sosial dan akan sangat jamak ditemukan di acara pernikahan, pemakaman dan juga perkumpulan suatu daerah, di acara tersebut akan dapat dengan mudah ditemukan rokok yang dibagikan untuk dihisap bersamasama (Nichter et al., 2008).

Industri rokok di Indonesia selama ini selalu dianggap sebagai industri yang sangat kreatif. Design bungkus rokok yang sangat bagus hingga ke penamaan merek rokok, sehingga seringkali terjadi kesulitan untuk menghentikan laju pemasaran rokok yang sangat tinggi apabila tidak ada aturan tegas untuk mengatasinya. Iklan-iklan rokok dibuat dan dapat ditemui dalam berbagai media baik cetak, elektronik, maupun luar ruang.

Media luar ruang menggunakan ukuran yang besar dan dapat dilihat dengan segera untuk menghasilkan perhatian bagi audience. Produk rokok adalah produk tembakau yang sangat erat kaitannya dengan kehidupan sosial, sehingga media luar ruang, menjadi salah satu media yang tepat dalam pemasaran produk (Belch \& Belch, 2003). Billboard menurut Katz (2003, pp. 3,88) termasuk dalam kategori print media atau media cetak, dengan ukuran yang sangat besar maka diharapkan pesan yang dibuat dapat diterima audience dengan lebih baik.
Kelebihan media luar ruang/billboard ini terletak pada ukuran, mobilitas, reach, dan biaya (Katz, 2003, pp. 90-91). Ukuran yang sangat besar memungkinkan exposure yang sangat tinggi bagi audience sehingga reach dari tujuan komunikasi dapat mencapai level yang tinggi, mobilitas yang baik karena memungkinkan dipindahkan kemanapun sesuai dengan audience yang dituju, serta biaya yang lebih terjangkau ketimbang iklan di media televisi.

Eksposure yang terlalu cepat karena terletak di pinggir jalan sangat memungkinkan audiens untuk tidak menerima pesan secara utuh, menjadi salah satu kelemahan dari media luar ruang. Kritik lain muncul mengenai lingkungan yang tercermar oleh berbagai jenis media luar ruang, sehingga memungkinan ketidak fokusan audiens akibat dari terlalu banyaknya kuantitas pesan (Katz, 2003, pp. 91-92).

Rumusan masalah penelitian ini adalah Persepsi Terhadap Pictorial Health Warning Iklan Luar Ruang Produk Rokok. Adapun tujuan penelitian ini adalah mengungkap persepsi dari masyarakat mengenai pencantuman Pictorial Health Warning pada media luar ruang. Setelah dalam penelitian sebelumnya (Priyatna \& Sani, 2014) mengungkap simbol-simbol dalam pictorial health warning, maka penelitian ini merubah sudut pandang dari pihak publik, terutama perokok, dalam melihat gambar peringatan tersebut. Penelitian dilakukan di beberapa kota besar seperti, Bandung, Jakarta, Yogyakarta, Malang dan Surabaya. 
Penelitian ini juga mencoba melihat apakah simbol-simbol yang diterapkan oleh Kementerian Kesehatan pada pictorial health warning diterima oleh audience dengan persepsi yang sama ataukah ada persepsi lain yang diterima oleh audience.

Hasil penelitian ini diharapkan dapat membantu pemerintah, utamanya Kementerian Kesehatan dalam melakukan kampanye pengurangan konsumsi rokok, dengan lebih efektif dan efisien terutama dalam penggunaan pictorial health warning. Hasil penelitian juga diharapkan akan memicu evaluasi kebijakan mengenai kampanye kesehatan, terutama rokok, di masa depan.

\section{METODE PENELITIAN}

Penelitian ini akan menggunakan studi deskriptif kualitatif. Studi deskriptif kualitatifitu sendiri dipilih karena kebutuhan untuk menjelaskan fenomena yang muncul di lapangan secara langsung, sejalan dengan yang dikatakan oleh Sandlowski (2000) qualitative descriptive study is the method of choice when straight descriptions of phenomena are desired. Sehingga karena kebutuhan untuk mendeskripsikan secara langsung tersebut maka pertanyaan penelitian yang muncul dalam studi deskriptif kualitatif adalah what kinds or varieties does the phenomenon appear in? What aspects does it have? (Elliot \& Timulak, 2005). Adapun tujuan dari studi deskriptif kualitatif adalah a comprehensive summarization, in everyday terms, of specific events experienced by individuals or groups of individuals (Lambert \& Lambert, 2012) yang memang sangat diperlukan untuk menjelaskan bagaimana persepsi dari masyarakat mengenai PHW varian gambar orang merokok dengan asap yang membentuk gambar tengkorak.

Metode lain yang akan digunakan adalah studi literatur yang akan menggali berbagai informasi terkait dengan objek penelitian.

Objek dalam penelitian ini adalah audience media luar ruang produk rokok di kota besar terutama para perokok. Objek akan diteliti dengan wawancara mendalam sehingga akan menghasilkan data kualitatif yang dapat dianalisis. Triangulasi yang dilakukan selain observasi langsung di lapangan adalah dengan studi literatur dan wawancara dengan pihak terkait masalah produk rokok.

Pengumpulan data yang dilakukan dalam penelitian ini menggunakan metode sebagai berikut:

1. Observasi yang dilakukan dalam mengumpulkan data dari objek penelitian, dalam hal ini PHW yang tersebar di beberapa tempat.

2. Wawancara mendalam dengan audience media luar ruang iklan rokok.

3. Studi Literatur dengan mencari data-data yang diperlukan melalui perpustakaan, internet dan dokumendokumen terkait lainnya.

Teknik Analisis Data yang dilakukan 
adalah sebagai berikut: data yang diambil dari observasi, wawancara dan juga studi literatur akan dianalisis menggunakan analisis deskriptif-kualitatif untuk wawancara dan studi literatur. Deskriptif di sini dapat diartikan sebagai menuturkan dan menafsirkan data yang diperoleh dari informan untuk memperoleh gambaran yang nyata mengenai proses pemilihan simbol-simbol dalam PHW yang harus dicantumkan di semua iklan rokok.

\section{HASIL DAN PEMBAHASAN}

Bagian ini akan membahas hasil dan pembahasan penelitian yang menjawab mengenai persepsi yang ada di masyakarat terutama kota besar dalam menyikapi PHW varian gambar orang merokok dengan asap yang membentuk gambar tengkorak. Kemudian akan membahas juga mengenai pemahaman simbol-simbol yang muncul dalam PHW varian gambar orang merokok dengan asap yang membentuk gambar tengkorak.

Hasil yang dicapai dalam penelitian ini didasarkan dari pengambilan data wawancara di lima kota besar. Data-data tersebut juga didukung oleh penggalian data melalui Kementerian Kesehatan dan juga pihak pemerintah.

Bab hasil dan pembahasan ini akan dibagi berdasarkan dua tujuan penelitian yang telah disebutkan di bab sebelumnya; yaitu persepsi masyarakat mengenai PHW varian orang merokok dengan asap yang membentuk gambar tengkorak dan kemudian pemahaman akan simbol-simbol yang ada dalam PHW varian orang merokok dengan asap yang membentuk gambar tengkorak.

\section{Persepsi mengenai PHW varian gambar orang merokok dengan asap yang membentuk gambar tengkorak.}

Media luar ruang yang menggunakan PHW dengan varian ini hampir pasti dapat ditemukan di setiap kota besar, sejalan dengan hasil observasi Priyatna \& Sani (2014) yang menyebutkan bahwa "PHW varian [ini] ditemukan di semua baligo, spanduk, billboard, dan media luar ruang lainnya terutama di kota-kota besar seperti Jakarta, Bandung, Yogyakarta, Malang, dan Surabaya". Karena media luar ruang yang menggunakan PHW ini dapat dengan mudah didapati di kota-kota besar, maka penelitian ini juga memfokuskan pada informan-informan yang tinggal di kota besar dan secara frekuensi lebih sering terpapar oleh PHW ini.

Informan yang ada dalam penelitian berasal dari berbagai profesi dari mulai pns, pegawai swasta, pemilik usaha, satpam, dan pengangguran. Sedangkan dari latar belakang pendidikan juga bervariasi dari mulai lulusan SMA hingga 1 sarjana ulusan luar negeri. Selain itu kriteria lainnya yang menjadi dasar adalah semua informan adalah perokok Lebarnya kriteria informan ini memang dilakukan untuk menjaring berbagai pendapat dari berbagai kalangan yang ada di masyarakat, sehingga 
diharapkan akan mendapatkan jawaban yang dapat mewakili tiap unsur di dalam masyarakat.

Persepsi yang muncul di masyarakat secara umum mengenai PHW varian ini di media luar ruang adalah kecenderungan gambar yang cenderung tidak membuat orang berhenti merokok. Seperti dikatakan oleh Hadi Wijaya, yang telah merokok selama 25 tahun, Ini aneh lagi, merokok membunuhmu malah gambarnya orang menikmati rokok. Aneh, makanya ngga pernah saya amat-amati, saya merokok aja terus ${ }^{1}$. Sejalan dengan ini Bajuri juga menyatakan Gambar ini aneh. Melarang orang untuk merokok tapi koq kaya yang malah ngiming-ngimingi orang merokok ${ }^{2}$. Pendapat lain diberikan oleh Juni bahwa gambar ini ga ngaruh ke orang beli rokok, karena waktu gambar ini keluar dulu saya malah milih beli rokok dengan bungkus ini kalo dibandingin dengan yang pake gambar lain $^{3}$.

Dari beberapa persepsi tersebut dapat terlihat bahwa PHW varian orang merokok dengan asap bentuk tengkorak tidak membuat orang berhenti merokok ataupun membeli rokok, sehingga menimbulkan pertanyaan mengapa PHW varian ini yang digunakan di media luar ruang. Selain dari persepsi yang menggangap bahwa PHW varian ini tidak berpengaruh bagi

1 Wawancara dengan Hadi Wijaya, Pemilik Galeri Perhiasan Perak, 40 Tahun, merokok 25 tahun, Yogyakarta.

2 Wawancara dengan Bajuri, PNS, 53 Tahun, merokok 40 tahun, Yogyakarta.

3 Wawancara dengan Juni, Supir Travel, 35 tahun, merokok 20 tahun, Surakarta para perokok maka ada pendapat lain yang sedikit mempertanyakan mengenai pemilihan PHW ini seperti yang dikatakan oleh Paijo:

gambar ini kemungkinan kalau banyak merokok akan jadi seperti ini (tengkorak). Tapi, ngga merokok pun kalau meninggal, pasti jadi tengkorak. Semua yang meninggal pasti jadi seperti itu kalo meninggal, walaupun tidak merokok ${ }^{4}$

pendapat informan lain yang menilik bahwa gambar ini dipertanyakan keefektifannya juga dikatakan oleh Fajar, gambar tengkoraknya malah ga keliatan karena fokusnya malah ke orangyangngerokok ini ${ }^{5}$. Misbah menambahkan kayak yang nikmat ngerokoknya ${ }^{6}$. Sejalan dengan itu Prasojo menambahkan bahwa ketika melihat PHW varian ini yang terlihat adalah merokok itu cowok banget, maskulin dan enak ${ }^{7}$.

Dalam kaitannya dengan penggunaan PHW varian ini dalam media luar ruang maka pendapat diantara informan hampir seragam yaitu tidak ada pengaruhnya seperti Paijo katakan bahwa gambar ini ga ada efeknya bagi perokok ${ }^{4}$, atau Fajar yang mengatakan bahwa gambar yang ini ga pengaruh dengan keinginan membeli rokok ${ }^{5}$. Dari sekian banyak wawancara dari para informan maka terlihat bahwa

4 Wawancara dengan Paijo, karyawan swasta, 47 tahun, merokok 20 tahun, Yogyakarta

5 Wawancara dengan Fajar, manajer café, 22 tahun, merokok 7 tahun, Bandung

6 Wawancara dengan Misbah, karyawan, 21 tahun, merokok 9 tahun, Bandung

7 Wawancara dengan Prasojo, mahasiswa, 25 tahun, merokok 11 tahun, Malang 
semua memiliki pemahaman yang sama dalam melihat PHW varian ini, yang sama sekali tidak berpengaruh dengan keinginan membeli atau melakukan aktifitas merokok.

\section{Simbol-simbol yang muncul dalam PHW varian gambar orang merokok dengan asap yang membentuk gambar tengkorak ini dipahami sama dengan yang diinginkan oleh pemerintah.}

Dalam menelaah persepsi mengenai simbol-simbol yang muncul dalam PHW varian orang merokok dengan asap yang membentuk gambar tengkorak ini maka muncul beberapa pemahaman yang tidak sesuai dengan yang diinginkan pemerintah.

Paijo misalnya melihat bahwa gambar tengkorak maksudnya meninggal, tapi bukan karena merokok orang jadi tengkorak, ngga kayak gitu. Tengkorak lambang peringatan, kayak di jalan jalan, lambang bahaya4. Fajar melihat bahwa Tengkorak orang udah meninggal ngeri liatnya tapi fokusnya pasti ke orang yang sedang ngerokok aja ${ }^{5}$. Prasojo melihat bahwa tengkorak ini memperlihatkan kesuraman, tapi si orang yang merokok ini melihat ke kanan tanpa melihat tengkorak itu, kayak nunjukin ketidakpedulian? Sedangkan Bajuri melihat tengkorak itu lambang kematian...tapi jangan salah, tengkorak juga lambang grup rock loh. Kayak Guns and Roses ${ }^{2}$.

Dari hasil wawancara terlihat bahwa tengkorak dipahami sebagai simbol negatif seperti kematian, namun juga ternyata simbol ini bahkan diabaikan ataupun maknanya berubah secara keseluruhan, karena semua informan dalam penelitian ini selalu fokus terhadap orang yang merokok dan bagaimana sang perokok ini melakukan aktifitasnya dengan "nikmat".

Para informan sendiri ketika ditanyakan mengenai gambar apa yang kirakira efektif dalam mengurangi konsumsi rokok, hampir semua seragam mengatakan bahwa mengurangi konsumsi rokok tidak dapat menggunakan gambar semata namun dari keinginan diri sendiri.

Pemerintah sendiri mengeluarkan PHW dengan maksud untuk mengurangi keinginan perokok untuk mengkonsumsi rokok, namun dari hasil penelitian ini, terutama varian orang merokok dengan asap berbentuk tengkorak, menunjukkan kurangnya efektifitas gambar ini dalam mengurangi konsumsi rokok.

\section{SIMPULAN DAN SARAN}

Simpulan dan saran yang dapat diajukan dalam laporan akhir ini adalah sebagai berikut:

1. Hasil penelitian menunjukkan adanya perbedaan perspektif mengenai eksekusi Pictorial Health Warning yang digunakan Kementerian Kesehatan, antara Pusat Promosi Kesehatan dengan perspektif perokok, sebagai informan.

2. Simbol yang muncul dalam PHW varian orang yang sedang merokok dengan asap membentuk gambar tengkorak 
tidak efektif dalam mengurangi konsumsi untuk para perokok.

3. Data-data tambahan, berupa dokumen yang diberikan Kementerian Kesehatan melalui Pusat Promosi Kesehatan, dapat memperkaya hasil penelitian ini.

4. Triangulasi yang dilakukan melibatkan para praktisi iklan dan komunikasi visual dalam rangka mencari simbol- simbol seperti apa yang lebih efektif utamanya bagi para perokok.

5. Sampai dengan saat ini, saran yang bisa diberikan mungkin lebih ke bagaimana penelitian yang dilakukan oleh para dosen dalam mengemban tridharma perguruan tinggi seharusnya dapat berguna secara filosofis maupun praktis bagi masyarakat Indonesia. 


\section{DAFTAR PUSTAKA}

Arnez, M. (2009). Tobacco and Kretek: Indonesian Drugs in Historical Change. Austrian Journal of South East Asian Studies vol 2 (1) , 49-69.

Belch, G. E., \& Belch, M. A. (2003). Advertising and Promotion, Sixth Edition. The McGraw-Hill Companies.

Deutsches Krebsforschungszentrum . (2013). Effectiveness of Pictorial Health Warnings on Cigarette Packages. Retrieved July 8, 2014, from German Cancer Research Center: http://www.dkfz.de/de/tabakkontrolle/download/Publikationen/AdWfP/ AdWfP_Pictorial_Health_Warnings.pdf

Elliot, R., \& Timulak, L. (2005). Descriptive and interpretive approaches to qualitative research. In J. Miles, \& P. Gilber (Eds.), A Handbook of Research Methods for Clinical and Health Psychology (pp. 147-159). Oxford: Oxford University Press.

Hanusz, M. (2000). Kretek: The Culture and Heritage of Indonesia's clove cigarettes. Jakarta: Equinox Publishing (Asia) Pte. Ltd.

Katz, H. E. (2003). The Media Handbook, Second Edition. Mahwah: Lawrence Erlbaum Associates, Inc.

Lambert, V. A., \& Lambert, C. E. (2012). Editorial: Qualitative Descriptive Research: An Acceptable Design. Pacific Rim International; Journal of Nursing Research, XVI (4), 255-256.

Priyatna, C. C., \& Sani, A. (2014). Mitos Kejantanan Pada Pictorial Health Warning Iklan Luar Ruang Produk Rokok. (U. R. Handaningtias, Ed.) Jurnal Riset Ilmu Komunikasi , V(10), 1-15.

Reid, A. (1985). From Betel-Chewing to Tobacco-Smoking in Indonesia. The Journal of Asian Studies Vol 44 No.3 , 529.

Ricklefs, M. (1993). A History of Modern Indonesia since c.1300 Second Edition. London : The MacMillan Press Ltd.

Sandlowski, M. (2000). Focus on Research Method; Whatever Happened to Qualitative Description. Research in Nursing \& Health, 334-340.

Sekjen Kementrian Kesehatan RI. (2014, June 24). Indonesia Harus Melek Bahaya Merokok. Retrieved July 10, 2014, from Depkes.go.id: http://depkes.go.id/index. php?vw=2\&id=NW.201407010002 
WHO. (2014). World Health Organization. Retrieved July 10, 2014, from WHO Health Warning Database: http://www.who.int/tobacco/healthwarningsdatabase/en/

World Health Organization. (2005). WHO Framework Convention on Tobacco Control. Geneva: WHO Press. 